\title{
Science and Sustainability
}

\section{Der Weg zu einer nachhaltigen Entwicklung stellt insbesondere die Wissen- schaft vor große Herausforderungen. Dabei ist ihr Beitrag ambivalent. Einer- seits ermöglicht der wissenschaftliche Fortschritt Problemlösungen, anderer- seits werden durch die tiefen Eingriffe in komplexe natürliche Prozesse selbst wieder neve Probleme erzeugt. Nołwendig sind daher eine Orientierung der Wissenschaft an Nachhaltigkeitskriterien sowie gesellschaftliche Institutionen, die die Qualität wissenschaftlicher Innovationen überpröfen (1).}

$\mathrm{T}$ Von Silvio Funtowicz, Jérome Ravetz and Martin O'Connor he strengthening of nations' scientific capability has been established as one of the cornerstones for the process of sustainable development. For example, Agenda 21, Chapter 35 emphasises the necessity of ,strengthening the scientific basis for sustainable management". The challenges to science are not only technical ones. There are also fundamental empirical and science methodology challenges for achieving better understanding of our environment and the planet's life-support systems (2). Finally there are moral and procedural challenges for defining the roles of science-based knowledge and innovations for poverty reduction, for governance of technological and environmental risks, for sustainable ecosystems management, and for effective communication of scientific information to achieve these goals.

Advances in science are opening up new domains of potential technological innovation, with potentially vast consequences for interventions in human health, energy supply, food production and environmental engineering. Many of the hopes for the contributions of science to development of long-run sustainable production and consumption patterns rely on the continuation of this impressive tradition of problem-solving success. Yet science and technology also bring new risks to society and new challenges for quality assurance. These new tasks are the concern both of the scientific community and of the wider political community.

The permanent process of pushing back the frontiers of knowledge and science-based interventions also confronts us, in new ways, with the limits to our knowledge and intervention capacity.
- Our knowledge advances permit more and more sophisticated interventions in ecosystem functioning and in the components of life itself; yet our scientific understanding of the physical environment and of the impacts of human activity on life process and ecosystems remains very incomplete and in many cases lags far behind our interventions.

- Science-based innovation has, in the past, contributed to industrialisation processes that have proven highly disruptive to ecosystems at local and global levels. Some of the new commercially attractive technologies may also be incompatible with ecological stability and environmental quality goals.

The promotion of science for sustainable development thus requires procedures for evaluating science and technology contributions against criteria for sustainability. Developing the necessary awareness for such evaluation is a major challenge. A long term perspective must be adopted that confronts these deep ambiguities of technological innovation. Building up an evaluation capability is a process that must involve policymakers and the public at large as well as the scientific community itself.

\section{Unwanted Side Effects}

A feature of many new domains of science-based innovation is their intervention in complex biological and ecosystem processes where quality assurance in terms of outcomes is almost impossible to conduct. This difficulty warrants some reflection. It has long been recognised that industrial production activities, mass consumption and intensive agriculture can have unwanted negative effects on ecosystems and environmental quality. What has more recently been emphasised is that some of the adverse consequences can be very long-term and also very difficult to control.
Examples of effects that can be felt over very long time-spans include land degradation, salinisation of aquifers, pesticide residues and emissions of durable toxic wastes that may accumulate in ecosystems and in food chains, radioactive wastes from nuclear reactors, and climate changes provoked by increased carbon dioxide (and other) greenhouse-effect gases into the Earth's atmosphere.

- Examples of interventions in social, economic and ecosystem processes that, once initiated, cannot easily be mastered include : changes or increased variability in hydrological and regional climate patterns due to the enhanced greenhouse effect; the 'environmental release' of 'transgenic' organisms for food production or other purposes; the cloning of animals (including perhaps humans).

As these and other examples suggest, we must now integrate the awareness that science-based interventions in complex natural processes can constitute, in themselves, a self-renewing source of problems that may jeopardise community livelihoods, health and future economic prospects. This is highly publicised for the risks in the electronuclear industry and in biotechnology applications based on genetic engineering. It is also true for the complicated yet fragile systems of food production and communication upon which modern societies depend. For example, many of the 'miracles' of increased productivity within the agro-food industry depend on a permanent utilisation of pest-control chemicals, fertilisers, hybrid or genetically modified stock, and other capital inputs. These technological developments can heighten the vulnerability of the food production systems in the face of technological, economic or natural disruptions. The intensive production is also, in many regions, having serious negative consequences for soil and water quality, which will undermine productivity in the long-term.

\section{Ambiguous Relationship}

A lesson that may be drawn from these examples is that the relationship between advances in science and in science-based technologies on the one hand, and sustainable development on the other hand, is multi-faceted and ambiguous. Just as the recognition of ecological constraints on the scale and forms of sustainable economic production and consumption means that "more output“ is not the same as "good output", so it has to be noted that more 


\section{The changed relation between problems and the prospects of science-based solutions}

- Science is no longer mainly offering the 'benefir' of new discoveries and applications, as a sort of addedvalue from investment.

- Rather it is placed in the reactive role of trying to fill a 'knowledge deficit' as awareness grows of problems such as hazardous wastes, water contamination, renewable resource depletion, climate change, other atmospheric potlutions and disuption to aquatic and terrestrial habitats.

- Analyses are, increasingly, being sought that can contribute to technological and policy responses. In this respect we

scientific knowledge put to work in innovations does not necessarily lead to a more sustainable economic process.

The principle of ,,sustainable development" has been conceived in response to perceived inadequacies of earlier models of economic development. Traditional growth-oriented economic development has not always improved the economic prospects of the poorer sections of the populations, in developing and developed countries alike. As well, the industrialisation process depends on natural resource exploitation, including fossil fuel and water resources, at rates and in ways that cannot be sustained indefinitely. New technologies such as nuclear energy and genetic engineering that show potential for relieving some environmental constraints, may also entail deepening environmental, health and technological risks.

Neither the advance of science in itself nor the widening of competitive markets can be expected to promote, as if ,naturally“, a path of sustainable development. On the contrary, the short-term orientations of much market-centred economic activity and the mixtures of commercial, military and other strategic preoccupations that motivate much sciencebased technology development, can be antagonistic to the goals of ecosystem resiliency, resource stewardship and social justice which may be considered foundations for long-term sustainability.

Therefore important changes in the relation between the problem identification and the prospects of science-based solutions are necessary (see box below).

To promote sustainable development there needs to be explicit identification of the kind of future socio-economic order that we wish to strive for, together with policies that encourage research, knowledge exchange and science applications in pursuit of these goals. can speak of a scientific activity that is designed around serving the gools of sustainable development.

- However this "science for sustainability" will be issuedriven, as well as curiosity-generated or mission-oriented. It will address problems that are salient for sustainability, regardless of their capability for a traditional "solution". These will include complex and difficult issues, even those where our knowledge is swamped by uncertainty, ignorance and value-conflict.

\section{New Challenges: Quality Assurance by Social Processes}

One of the implications is that the priorities for science content must evolve if science is to contribute effectively as a force for sustainable development. This is a message that has to be communicated to the scientific community itself. Scientific practice is not fundamentally 'valuefree' but it has to find its justifications by reference to prevailing social concerns. The object of the scientific endeavour in this new context may well be to enhance the process of the social resolution of the problem, including the participation and mutual learning among stakeholders, rather than a definitive ,solution“ or technological implementation.

The normative orientations of sustainable development must, in this regard, guide scientific work and technology applications towards innovations that respect fundamental sustainability values such as local ecosystem resiliency, mitigation of global climate change impacts, energy efficiency, food security, and enhanced problemsolving capacities of local populations. An important part of this guidance and justification, we suggest, is the design and implementation of agreed social processes for quality assurance in science knowledge and technological implementations. This will entail the emergence of new social institutions to perform the quality assurance function. In this style of science, place-specific knowledge and resources of local communities will need to be integrated as complementary to the universal knowledge of traditional scientific practice.

The complexities of modern science-based production and environmental engineering practices pose radical new challenges for public policy. Those who place their faith in science and technology may suggest that knowledge advances can, in themselves, in due time bring solutions to the dangers, disruptions and dilemmae that earlier science and technological interventions have generated. We propose, however, that the inherent complexity, high stakes and urgency of sustainable development is not something that can be handled by technological advances alone. If sustainability goals are to be achieved, science and technological development as potential forces for public good have to be guided by a quality control process based on explicit ethical, political and epistemological reflection. New notions of social responsibility in public policy and science will need to be explored.

In the light of these challenges, overcoming the communication gap between scientists, policy makers and the public at large requires new approaches. The old conception, of a one-way traffic of information from the experts to the public has to be replaced by a partnership among those involved in the process. The deep involvement of policy makers and publics in the quality assurance of innovations in science and technology becomes necessary. It is in such tasks that the above-mentioned communication gap between scientists, policy makers and the general public can be overcome; and this is the principal challenge facing science for sustainable development today.

\section{Anmerkungen}

(1) Dieser Artikel ist eine gekürzte Fassung von Silvio Funtowicz, Jérome Ravetz and Martin O'Connor: Challenges in the Utilisation of Science for Sustainable Development. Background Note No.l for the Panel Discussion "Science and Sustainable Development" at the Sixth Session of the Commission on Sustainable Development (New York, 20 April to 1 May 1998).

(2) Vgl. zu dieser Problematik auch das Spezial Ökologisch-ökonomische Komplexität in der letzten Ausgabe 3-4/98 von Ökologisches Wirtschaften.

Die Autoren
Sylvio Funtowicz ist wiss. Mitarbeiter am ISIS - Insti-
tute for Systems, Informatics and Safety in Ispra
(Italien).
Kontakt: Tel. +39/332-785934, Fax -789 394 .
Dr. Jérome Ravetz ist Direktor der Research Methods
Consultancy, London.
Kontakt: Tel. +44/171-723 0912 , Fax -4873660.
Dr. Martin 0 'Connor ist Professor am C3ED - Centre
d'Économie et d'Ethique pour I'Environement et de
Développement, Université de Versailles, Frankreich.
Kontakt: Tel. +33/1 $3925-5375$; Fax - 5300


(c) 20I0 Authors; licensee IÖW and oekom verlag. This is an article distributed under the terms of the Creative Commons Attribution Non-Commercial No Derivates License (http://creativecommons.org/licenses/by-nc-nd/3.o/), which permits unrestricted use, distribution, and reproduction in any medium, provided the original work is properly cited. 